\title{
Hubungan Antara Pengetahuan Ibu Tentang Diare Dengan Penanganan Pertama Diare Pada Anak Usia 1- 5 Tahun (Studi Kasus Di Polindes Geger Kecamatan Turi Kabupaten Lamongan Tahun 2018)
}

\author{
Kustini \\ Program Studi Diploma III Kebidanan Universitas Islam Lamongan \\ Email: Custiniwil@gmail.com
}

\begin{abstract}
ABSTRAK
Diare merupakan suatu kondisi di mana terjadi perubahan dalam kepadatan dalam kepadatan dan karakter tinja cair dan dikeluarkan tiga kali atau lebih perhari. Tujuan penelitian ini adalah mengetahui Hubungan antara tingkat pengetahuan ibu tentang diare dengan penanganan pertama diare pada anak usia 1-5 tahun di Polindes Geger Kecamatan Turi Kabupaten Lamongan

Desain penelitian ini merupakan Analitik korelasional. Populasi penelitian adalah seluruh ibu yang mempunyai balita usia 1-5 tahun yang balitanya mengalami diare, sebanyak 74 orang. Pemilihan sampel dengan tehnik sampling Non Probability Sampling tipe Simple Random Sampling dengan sampel 34 orang dengan variabel independent pengetahuan ibu tentang diare dan variabel dependent penanganan pertama diare. Uji analisis dan penelitian ini adalah Spearman ro dengan tingkat kemaknaan $\alpha$ 0,05.

Hasil penelitian menunjukkan bahwa sebagian besar responden mempunyai pengetahuan baik yaitu 16 orang (47\%) dan sebagian besar responden mempunyai penanganan pertama yang benar yaitu 25 orang $(73 \%)$.

Kesimpulan dalam penelitian ini adalah tidak terdapat hubungan antara pengetahuan ibu tentang diare dengan penanganan pertama diare pada anak usia 1-5 tahun. Untuk itu diharapkan ibu dapat mencegah dengan cara selalu hidup sehat maka anak yang sehat tidak terserang diare dan apabila terjadi diare maka dilakukan penanganan pertama diare pada anak dengan cara memberikan cairan oralit sehingga anak tidak sampai terjadi dehidrasi dan angka kematian balita karena diare dapat menurun.
\end{abstract}

Kata Kunci : pengetahuan tentang diare, penanganan pertama

\section{Pendahuluan}

Anak merupakan aset masa depan yang akan melanjutkan pembangunan di suatu negara. Masa perkembangan tercepat dalam kehidupan anak terjadi pada masa balita. Masa balita merupakan masa yang paling rentan terhadap serangan penyakit. Terjadinya gangguan kesehatan pada masa tersebut, dapat berakibat negatif bagi pertumbuhan anak itu seumur hidupnya (Soetjiningsih, 2008, Adzania, 2014). Penyakit yang masih perlu diwaspadai menyerang balita adalah diare (Sutoto, Indriyono, 1996, Widjaja, 2003) karena diare juga masih merupakan masalah kesehatan yang penting di Indonesia. Walaupun angka mortalitasnya telah menurun tajam, tetapi angka morbiditas masih cukup tinggi Penanganan diare yang dilakukan secara baik selama ini membuat angka kematian akibat diare dalam 20 tahun terakhir menurun tajam. Walaupun angka kematian sudah menurun tetapi angka kesakitan masih cukup tinggi. Lama 
diare serta frekuensi diare pada penderita akut belum dapat diturunkan (Lisa Ira 2012).

Menurut hasil survei Program Pemberantasan (P2) Diare di Indonesia menyebutkan bahwa angka kesakitan diare di Indonesia meningkat drastis dibandingkan dengan jumlah pasien diare pada tahun sebelumnya, yaitu sebanyak 1.436 orang. Di awal tahun 2016, tercatat 2.159 orang dengan periode diare balita adalah 1,0 - 1,5 kali per tahun pada Tahun 2017 angka kesakitan penyakit ini meningkat menjadi 574 per 1.000 penduduk dan merupakan penyakit dengan frekuensi KLB kedua tertinggi setelah DBD. Survei Departemen Kesehatan (2007), penyakit diare menjadi penyebab kematian nomor dua pada balita, ke tiga pada bayi, dan ke lima pada semua umur. Kejadian diare pada golongan balita secara proporsional lebih banyak dibandingkan kejadian diare pada seluruh golongan umur yakni sebesar $55 \%$. Sedangkan kejadian diare akut di Indonesia diperkirakan masih sekitar 60 juta periode setiap tahunnya dan 1-5 \% diantaranya berkembang menjadi diare kronis. Berbagai penelitian menunjukkan bahwa dari $35 \%$ seluruh kematian balita akibat diare disebabkan oleh diare akut.

Data dari Dinkes Propinsi Jawa Timur didapatkan penderita diare yang dapat dilayani oleh pelayanan pada tahun 2016 adalah sebesar 4.870 penderita, tapi pada tahun 2017 cakupan yang diterima mencapai 5.960 penderita dan yang meninggal sekitar 3330 penderita $(55 \%)$ disebabkan oleh diare dan 2630 penderita (44\%) dinyatakan sembuh.

Data dari Dinkes Lamongan didapatkan kasus diare pada balita di Kabupaten Lamongan pada tahun 2017 merupakan penyebab kematian balita nomor dua dan pertama disebabkan oleh DBD dengan kasus diare di Lamongan sebanyak 7.293 penderita, dengan rata rata orang tua mereka berpendidikan SD dan SMP. Dari banyaknya penderita diantaranya 2350 penderita dalam kondisi dehidrasi, sehingga hampir $26 \%$ meninggal saat dilakukan rujukan ke rumah sakit. Dan 5\% diantaranya dapat ditangani saat berada dirumah sakit. Sedangkan 4943 penderita yang lain dilakukan rujukan ke puskesmas sekitar $37 \%$ penderita dapat ditangani saat berada dipuskesmas dan $23 \%$ dilakukan rujukan ke rumah sakit sedangkan 10\% meninggal, sedangkan angka kejadian diare di Puskesmas Turi pada Tahun 2017 dalam 1 Tahun terakhir sebanyak 670 penderita, sedangkan jumlah angka kejadian diare pada balita bulan April -Juni dipolindes Geger sebanyak 74 balita.

Pada umumnya penyakit diare terdapat gejala diantaranya adanya peningkatan buang air besar (BAB) tiga kali atau lebih per hari disertai perubahan tinja menjadi cair dengan atau tanpa lendir dan darah. Selain itu biasanya ditandai anak menjadi cengeng, gelisah, suhu tubuh meningkat, nafsu makan menurun sampai tidak ada nafsu makan. Berdasarkan penelitian yang dilakukan diketahui banyak faktor yang mempengaruhi kejadian diare akut pada balita. Faktor tersebut diantaranya adalah faktor dari lingkungan, keadaan sosial ekonomi dan pengetahuan ibu. Faktor- faktor tersebut merupakan faktor dari luar dan dapat diperbaiki sehingga dengan perbaikan faktor resiko tersebut diharapkan dapat menekan angka kesakitan dan kematian diare pada balita.

Angka kejadian diare yang seharusnya tidak terjadi seandainya orang tua khususnya ibu mengetahui bagaimana penatalaksanaan apabila balitanya diare. Salah satu resiko yang ikut berperan dalam timbulnya diare kebanyakan karena kurangnya pengetahuan ibu dalam hal higiene yang kurang, baik perorangan maupun lingkungan, pola pemberian makanan, sosio ekonomi dan sosio budaya. Orang yang memiliki tanggung jawab dalam meningkatkan kesehatan anak salah satunya adalah ibu karena ibu adalah orang 
yang paling dekat dengan anak dan berperan dalam merawat anaknya. Dengan demikian pengetahuan ibu tentang diare secara tidak langsung berpengaruh terhadap penurunan angka kejadian diare Sehingga upaya pertolongan pertama di rumah dalam menangani balita yang terkena diare supaya tidak terjadi dehidrasi dapat dengan cara memberikan minum air putih yang dimasak atau oralit dan mempertahankan rehidrasi (Dep.Kes.RI, 1999). Maka diperlukan peningkatan pengetahuan ibu tentang penatalaksanaan dan pencegahan penyakit diare pada balita dapat ditingkatkan melalui berbagai penyuluhan mengenai diare. Hal ini, merupakan salah satu peran bidan sebagai pendidik (Healt Education) dalam memberikan pendidikan kesehatan (promosi kesehatan) kepada individu, keluarga, kelompok dan masyarakat maupun bentuk desiminasi ilmu kepada peserta didik kebidanan, antara sesama bidan atau tenaga kesehatan lain (Gaffar, 1999)

\section{Metode penelitian}

Jenis penelitian ini adalah analitik adalah peneliti tidak memberikan suatu perlakuan pada obyek yang diteliti.(Nursalam, 2008). Rancang bangun penelitian adalah hasil akhir dari suatu tahap keputusan yang dibuat oleh peneliti berhubungan dengan bagaimana suatu penelitian biasa ditetapkan (Nursalam, 2008). Rancang bangun penelitian yang digunakan adalah analitik korelasional yaitu mengkaji hubungan antar variabel. (Nursalam, 2008 : 82). Sedangkan pengukuran yang digunakan adalah cross secsional adalah jenis penelitian yang menekankan pada waktu pengukuran atau observasional data independent dan dependent hanya satu kali pada satu saat. ( Nursalam, 2003: 85 ). Sehingga penelitian ini bertujuan untuk mengungkapkan hubungan korelasi antar variabel dependen dan independent.

Pada penelitian ini populasi adalah ibu yang mampunyai balita diare di Polindes
Geger Kecamatan Turi Kabupaten Lamongan pada bulan April- Juni sebanyak $74 \mathrm{ibu}$

Sample yang di gunakan dalam penelitian ini adalah ibu yang mempunyai balita yang sakit diare di Polindes Geger Kecamatan Turi Kabupaten Lamongan pada bulan Agustus 2018 sebanyak 34 penderita .

Teknik sampling yang digunakan dalam penelitian adalah : simple random sampling merupakan sampel dengan cara jenis probabilitas yang sederhana untuk mencapai sampling ini setiap elemen di seleksi secara randem (acak) jika sampling frame kecil, nama bisa ditulis pada secarik kertas diletakkan dikotak diaduk dan diambil secara acak setelah semua terkumpul.

Analisis yang dilakukan untuk mengetahui hubungan antara pengetahuan ibu tentang Diare dengan penanganan diare pada anak usia 1-5 tahun dengan menggunakan uji statistik dengan rumus kolerasi spearm an Rho yang menggunakan sistem SPSS ( Statistical Product and Service Solution ) versi 12.00 for windows dengan tingkat kemaknaan 0,05 .

\section{Hasil Penelitian}

1. Tingkat Pengetahuan Ibu Tentang Diare

Tabel 1. Distribusi Responden Berdasarkan Pengetahuan Ibu Tentang Diare Di Polindes Geger Kecamatan Turi Kabupaten Lamongan Agustus 2018.

\begin{tabular}{ccc}
\hline $\begin{array}{c}\text { Pengetahuan Ibu } \\
\text { Tentang Diare }\end{array}$ & Frekuensi & $\begin{array}{c}\text { Prosentase } \\
(\%)\end{array}$ \\
\hline Baik & 16 & 47 \\
Cukup & 12 & 35 \\
Kurang & 6 & 18 \\
\hline Total & 34 & 100 \\
\hline
\end{tabular}

Tabel 1 diatas menunjukkan bahwa hampir sebagian besar 16 responden (47\%) yang berpengetahuan baik dan 
sebagian kecil 6 responden (18\%) yang berpengetahuan kurang.

2. Penanganan Pertama Diare Pada Anak Usia 1-5 Tahun

Tabel 2 Distribusi Responden Berdasarkan

Penanganan Pertama Diare

Pada Anak Usia 1-5 Tahun Di

Polindes Geger Kecamatan

Turi Kabupaten Lamongan Agustus 2018.

\begin{tabular}{lcc}
\hline $\begin{array}{c}\text { Penanganan } \\
\text { Pertama } \\
\text { Diare }\end{array}$ & Frekuensi & $\begin{array}{c}\text { Prosentase } \\
(\%)\end{array}$ \\
\hline Benar & 25 & 73 \\
Salah & 9 & 26 \\
\hline Total & 34 & 100 \\
\hline \multicolumn{3}{c}{ Tabel 2 diatas menunjukkan bahwa } \\
hampir sebagian besar 25 responden \\
$(73 \%)$ yang melakukan penanganan secara \\
benar
\end{tabular}

3. Tabulasi Silang Pengetahuan Ibu Tentang Diare Dengan Penanganan Pertama Diare Pada Anak Usia 1-5 Tahun

Tabel 3 Tabulasi Silang Pengetahuan Ibu Tentang Diare Dengan Penanganan Pertama Diare Pada Anak Usia 1-5 Tahun.Di Polindes Geger Kecamatan Turi Kabupaten Lamongan Agustus 2018

\begin{tabular}{|c|c|c|c|c|c|c|}
\hline \multirow[t]{3}{*}{ Pengetahuan } & \multicolumn{4}{|c|}{ Penanganan pertama } & \multicolumn{2}{|c|}{ Total } \\
\hline & \multicolumn{2}{|c|}{ Benar } & \multicolumn{2}{|c|}{ Salah } & & \\
\hline & Jmlh & $\%$ & Jmlh & $\%$ & Jmlh & $\%$ \\
\hline Baik & 13 & $31,3 \%$ & 3 & $18,8 \%$ & 16 & $100,0 \%$ \\
\hline Cukup & 8 & $56,7 \%$ & 4 & $33,3 \%$ & 12 & $100,0 \%$ \\
\hline Kurang & 4 & $56,7 \%$ & 2 & $33,3 \%$ & 6 & $100,0 \%$ \\
\hline Total & 25 & $73,5 \%$ & 9 & $26,5 \%$ & 34 & $100,0 \%$ \\
\hline
\end{tabular}

dijelaskan bahwa 16 responden yang berpengetahuan baik setengahnya 13 responden $(81,3 \%)$ melakukan penanganan pertama diare dengan benar dan sebagian kecil 3 responden $(18,8 \%)$ melakukan penanganan diare dengan salah. Dari hasil uji spearman's rho didapatkan nilai $\mathrm{p}=$ 0,381 dimana $p>0,05$, hal ini menunjukkan bahwa Ho diterima artinya tidak terdapat hubungan antara pengetahuan ibu tentang diare dengan penanganan pertama diare pada anak usia 1-5 tahun di Polindes Geger Kecamatan Turi Kabupaten Lamongan 2018.

\section{PEMBAHASAN}

Hasil penelitian dilakukan terhadap 34 responden memiliki balita di Polindes Geger Kecamatan Turi Kabupaten Lamongan, didapatkan ibu yang berpengetahuan baik tentang diare yaitu 16 responden (47\%). Banyaknya pengetahuan ibu yang baik karena responden memahami, mengaplikasikan, menganalisa, mensistesis dan mengevaluasi terhadap suatu materi yang berkaitan dengan diare. (Notoadmojo, 2003). Pengetahuan merupakan hasil dan tahu dan terjadi setelah orang melakukan pengindraan terhadap obyek tertentu (Notoadmojo, 2003 : 121). Menurut Nursalam dan pariani (2001) baik dan kurangnya pengetahuan seseorang dapat dipengaruhi oleh beberapa faktor antara lain sifat kepribadian, bakat pembawaan, intelegensi, motivasi, usia dalam penelitian ini ternyata mendukung hampir sebagian responden berpengetahuan baik menurut usia adalah sekitar 21-30 tahun yaitu 17 responden $(50 \%)$. Semakin dewasa usia seseorang maka akan semakin mudah untuk menerima informasi yang didapatkan. Menurut Gunarsa (2002 : 34) berdasarkan usia perkembangan, kelompok usia tersebut merupakan usia dewasa muda dan usia produktif, yang merupakan masa dengan keadaan fisik yang optimal karena belum terjadi degenerasi, termasuk daya ingat terhadap informasi yang diterima. Hasil penelitian dilakukan terhadap 34 responden memiliki balita di Polindes Geger Kecamatan Turi Kabupaten Lamongan, di dapatkan ibu yang melakukan penanganan pertama yang benar 25 responden $(73 \%)$ masih terdapat kasus diare pada anak balita ini ditinjau dari masih tingginya perilaku dalam 
penanganan dan pencegahan diare oleh ibu serta semakin terperosoknya perekonomian rakyat, sehingga pemanfaatan pelayanan kesehatan dan usaha pencegahan terhadap penyakit semakin berkurang (Notoatmodjo, 2003) didukung dengan data penelitian sebagian besar berpendidikan SMP 20 responden (60\%). Sehingga respon seseorang terhadap sistem pelayanan kesehatan baik yaitu ibu melakukan penanganan pertama pada anak diare dengan cara membawa ketenaga kesehatan terdekat untuk mendapatkan pengobatan. Perilaku ini menyangkut respon terhadap fasilitas pelayanan, cara pelayanan, dan obatobatanya yang terwujud dalam pengetahuannya, persepsi, sikap yang dihubungkan dengan perilaku terhadap sakit dan penyakit ini dengan sendirinya sesuai dengan tingkat pencegahan penyakit, yakni perilaku sehubungan dengan peningkatan dan pemeliharaan kesehata. Sehingga upaya pertolongan pertama di rumah dalam menangani balita yang terkena diare supaya tidak terjadi dehidrasi dapat dengan cara memberikan minum air putih yang dimasak atau oralit dan mempertahankan rehidrasi (Dep.Kes.RI, 1999). Maka diperlukan peningkatan pengetahuan ibu tentang penatalaksanaan dan pencegahan penyakit diare pada balita dapat ditingkatkan melalui berbagai penyuluhan mengenai penanganan dan pencegahan diare.

\section{Hubungan Antara Pengetahuan Ibu Tentang Diare Dengan Penanganan Pertama Diare Pada Anak Usia 1-5 Tahun.}

Hasil dari uji spearman's rho didapatkan nilai $\mathrm{p}=0,381$ dimana $\mathrm{p}>$ 0,05 , hal ini menunjukkan bahwa Ho diterima artinya tidak terdapat hubungan antara pengetahuan ibu tentang diare dengan penanganan pertama diare pada anak usia 1-5 tahun di Polindes Geger Kecamatan Turi Kabupaten Lamongan 2018. Dengan pengetahuan ibu yang hampir sebagian adalah baik, ibu mampu mempertahankan kesehatan keluarga terutama balita. Pada balita yang belum dapat menjaga kebersihan dan menyiapkan makanan sendiri, kualitas makanan dan minuman tergantung pada ibu pengasuh utama.

Makin tinggi pengetahuan seseorang maka makin mudah untuk menerima informasi sesuai dengan tahapan adopsi perilaku yaitu awarenes, interest, evaluation, trial dan adoption yaitu subyek berperilaku baru sesuai dengan pengetahuan, kesadaran dan sikap terhadap stimulus. Dimungkinkan setelah ini memperoleh stimulus tentang diare, mereka tertarik kemudian menimbang baik buruknya informasi tersebut. Setelah diyakini baik ibu mulai mencoba untuk berperilaku baik yaitu pada saat anak diare diberikan pertolongan pertama saat dirumah. Kemudian ibu berperilaku baru sesuai dengan pengetahuan, kesadaran, dan sikap terhadap stimulus atau informasi yang di terimanya.

Ternyata tidak semua pengetahuan dapat menjamin terjadinya perubahan perilaku sebab perilaku tersebut kadang memerlukan dukungan material (Notoatmodjo, 2003) maka dari hasil penelitian didapatkan bahwa responden yang berpengetahun baik namun salah dalam penanganan pertama yaitu 3 responden $(18,8 \%)$.

Situasi ini menggambarkan bahwa kejadian diare tidak hanya dipengaruhi oleh pengetahuan karena pengetahuan tidak berpengaruh terhadap sikap dan tindakan ibu untuk melakukan penanganan pertama diare pada balita. Pengetahuan tentang diare dimaksudkan agar anak yang sudah mengalami diare tidak jatuh pada keadaan yang lebih parah sehingga penanganan pertama saat dirumah dengan memberikan oralit, pada daerah tertentu anak diberikan jamu-jamuan ada juga yang tidak diberikan apapun dengan alasan anak tidak mau. Pada daerah perkotaan anak diare tanpa dilakukan penanganan pertama 
saat dirumah melainkan langsung dibawa ketenaga kesehatan terdekat. Beberapa cara dilakukan orang tua terutama ibu untuk melakukan penanganan pertama pada saat anak diare maka diperlukan peningkatan pengetahuan ibu tentang penatalaksanaan dan pencegahan diare pada balita dapat ditingkatkan melalui berbagai penyuluhan mengenai penanganan dan pecegahan diare karena diare tidak hanya dipengaruhi oleh pengetahuan dalam hal penangana melainkan di pengaruhi oleh lingkungan, makanan, sosial ekonomi maka ibu harus selalu menjaga kesehatan dan kebersihan keluarga dan lingkungan agar anak tidak mudah terserang diare sehingga angka kematian balita karena diare dapat menurun.

\section{SIMPULAN}

Berdasarkan analisis data statistik dari 34 responden di Polindes Geger Kecamatan Turi Kabupaten Lamongan dapat disimpulkan sebagai berikut :

1. Pengetahuan ibu tentang diare pada anak usia 1-5 Tahun di Polindes Geger Kecamatan Turi Kabupaten Lamongan hampir sebagian besar berpengetahuan baik

2. Penanganan pertama diare pada .anak usia 1-5 Tahun di Polindes Geger Kecamatan Turi Kabupaten Lamongan yang diberikan pada saat anak diare sebagian besar benar

3. Tidak ada hubungan antara pengetahuan ibu tentang diare dengan penanganan pertama diare pada anak usia 1-5 tahun di Polindes Geger Kecamatan Turi Kabupaten Lamongan 2018.

\section{SARAN}

\section{Pihak Institusi}

Hasil penelitian ini diharapkan dapat menambah kajian ilmu dalam bidang kesehatan dan memberi gambaran bagi peneliti selanjutnya untuk melakukan penelitian lebih baik.

\section{Bagi Peneliti}

Hasil Penelitian ini didapatkan tidak ada hubungan antara pengetahuan ibu tentang diare dengan penangana pertama diare pada anak usia 1-5 tahun karena diare tidak hanya dipengaruhi oleh pengetahuan mengenai dipengaruhi oleh beberapa faktor diantaranya lingkungan, ekonomi, individu, makanan sehingga diharapkan untuk penelitian selanjutnya dapat mengambil beberapa faktor yang lain sehingga mengetahui ada atau tidaknya hubungan.

3. Bagi Puskesmas

Hasil penelitian ini dapat menjadi sumber informasi kepada kepala Puskesmas dan sebagai bahan pertimbangan dalam meningkatkan mutu pelayanan Puskesmas salah satunya untuk program $\mathrm{P} 2$ diare.

4. Bagi Responden

Mengetahui penyebab diare serta dapat melakukan pencegahan.

\section{REFERENSI}

Bobak. Lowder Milk. Jensen. Buku Ajar Keperawatan Maternitas, Edisi 4. EGC.

Budiarto S. 2010. Biostatistik untuk kedokteran dan Kesehatan Masyarakat. Jakarta. EGC.

Etna Francis Paath, S.Sos dkk, Gizi Dalam Kesehatan Reproduksi, Cetakan I 2005, EGC.I

Kamus Besar Bahasa Indonesia, 2008.

Moctar Rustam, Synopsis Obstetri, Jakarta. EGC.

Mudzakir, D. Ahmad, Sutrisno, Joko, 2007, Psikologi Pendidikan, Semarang Pustaka.

Nursalam, Konsep dan Penerapan Metode Penelitian Ilmu Keperawatan, 
Vol. 10 No. 2, Desember 2018

Penerbit Salemba Medika, Mei 2013.

Nursalam dan Siti Pariani 2010, Metodologi Penelitian Ilmu Keperawatan Jakarta. S. Agung Seto.

Prof. Dr, dr. Sarwono Prawirohardjo, S.POG, Emu Kebidanan, Yayasan Bina Pustaka Sarwono Prawirohardjo, Jakarta: 2015.

Prof. dr. Ida Bagus Gde Manuaba, SPOG, Ilmu Kebidanan, Penyakit Kandungan dan Keluarga Berencana untuk Pendidikan Bidan, Cetakan 1,2008, EGC.

Prof. Dr. Soekidjo Notoatmodjo, Ilmu Kesehatan Masyarakat, Prinsip-Prinsip Dasar, Penerbit Rineka Cipta.

Prof. Dr. Suharsimi Arikunto, Prosedur Penelitian Suatu Pendekatan Praktek, Rineka Cipta, Cetakan ke 13, Agustus 2006.

Syaifudin Azwar, MA, Sikap Manusia Teori dan Pengukurannya.

www.google.com (Prof. dr. Ida Bagus Gde Manuaba, SPOG), hyperemesis number, 2009. 